\title{
Shifting Dominance of Subcatchment Water Sources and Flow Paths in a Glacial Floodplain, Val Roseg, Switzerland
}

\author{
Florian Malard, ${ }^{*}$ \\ Klement Tockner, \\ and $J . V$. Ward
}

Department of Limnology, EAWAG/ ETH, Überlandstrasse $133, \mathrm{CH}-8600$ Dübendorf, Switzerland.

*Author for correspondence, present address: Hydrobiologie et Ecologie Souterraines, ESA CNRS 5023, Université Claude Bernard-Lyon 1Bât.403, 43 Bd 11 Novembre 1918, F-69 622 Villeurbanne Cedex, France. malard@univ-lyon1.fr

\begin{abstract}
The influence of river-catchment hydrological interactions on discharge patterns, lotic ecosystem size, and surface water chemistry were investigated in a glacial floodplain of the Swiss Alps (Val Roseg). Discharge, the extent and form of the stream network, specific conductance, and concentrations of major ions were measured periodically at multiple sites across the floodplain from August 1996 to January 1998. These data are used to (1) describe the seasonal cycle of contraction and expansion of the floodplain channel network and (2) identify hydrochemical tracers for detecting different sources and pathways of water. The seasonal changes in discharge, spatiotemporal patterns of channel length, and water chemistry within the floodplain are linked to the shifting dominance of different hydrologic reservoirs and flow paths within the catchment. During the expansion phase in spring, snowmelt is the main source of water for the entire floodplain, although it circulates via subsuface pathways on the catchment slopes before entering the floodplain. Peak discharge and maximum expansion of the channel network in summer are associated with the melting of the glaciers. Englacial water enters the floodplain mainly via surface flow paths and is distributed across the floodplain via surface connectivity and shallow groundwater pathways. During the contraction phase in autumn, seepage of subglacial water from the main channel is the primary water source for the upper floodplain. In the lower floodplain, surface flow is sustained by upwelling of deep alluvial and hillslope groundwaters. The relative contribution of deep groundwaters increases during winter, a phase of low discharge and maximum contraction of the channel network.
\end{abstract}

\section{Introduction}

Aquatic ecologists have long been aware of the crucial importance of catchment-stream connections in determining the hydrological, chemical, and biological features of freshwater ecosystems (Hynes, 1975; Townsend, 1996; Allan and Johnson, 1997). Considering hydrological fluxes, the stream is no longer considered as a conduit for the downstream transport of overland and subsurface water from the catchment but as "part of the catchment's downvalley and downgradient transport of water and solutes" (Bencala, 1993). This contrasting view emerged because research on the hyporheic zone showed that most streams continuously exchange water with underlying groundwater reservoirs that are integral parts of the catchment (Valett et al., 1996; Brunke and Gonser, 1997).

Knowledge of catchment-stream interactions is a prerequisite for understanding the ecological functioning of floodplain river systems. However, these interactions are extremely complex because they involve multiple water sources and hydrologic routings (Jolly, 1996; Parch et al., 1996; Petts and Amoros, 1996). Changes over space and time, in the contribution of different hydrologic reservoirs of the catchment, and the relative importance of flow paths were shown to affect the discharge and the size of different water bodies of lowland river floodplains (Roux, 1982; Forsberg et al., 1988; Heiler et al., 1995; Stanley et al., 1997). This effect is expected to be even more pronounced in glacial floodplain rivers that are characterized by a distinct seasonal flow regime due to the melting of ice masses in summer (Milner and Petts, 1994).
The objective of this paper is to examine the influence of river-catchment hydrological interactions on discharge patterns and lotic ecosystem size in a glacial floodplain of the Swiss Alps (Val Roseg). We hypothesized that (1) the seasonal flow regime would result in a predictable cycle of expansion and contraction of the stream network, and (2) variations in discharge and stream density would reflect a shift in the relative contribution of different hydrologic reservoirs and flow paths of water within the catchment. Discharge, the extent and form of the channel network, specific conductance, and the concentrations of major ions were measured at multiple sites across the glacial floodplain periodically from August 1996 to January 1998. First, we describe the seasonal cycle of contraction and expansion of the floodplain channel network. Second, we identify hydrochemical tracers for detecting different sources and pathways of water. Lastly, hydrochemical tracers are used to build up a conceptual model that relates seasonal changes in discharge, and spatio-temporal patterns of channel length within the floodplain, to the relative importance of different hydrologic reservoirs and flow paths of water operating within the catchment.

\section{Study Site}

The upper catchment of the Roseg River, a tributary of the River Inn, is located in the Bernina Massif of the Swiss Alps (Fig. 1A). Its area is $49.5 \mathrm{~km}^{2}$ with elevations ranging from 1990 to $4049 \mathrm{~m}$ a.s.l. (mean elevation: $2840 \mathrm{~m}$ ). It receives an average of $1.6 \mathrm{~m}$ of precipitation each year, of which about half falls as 


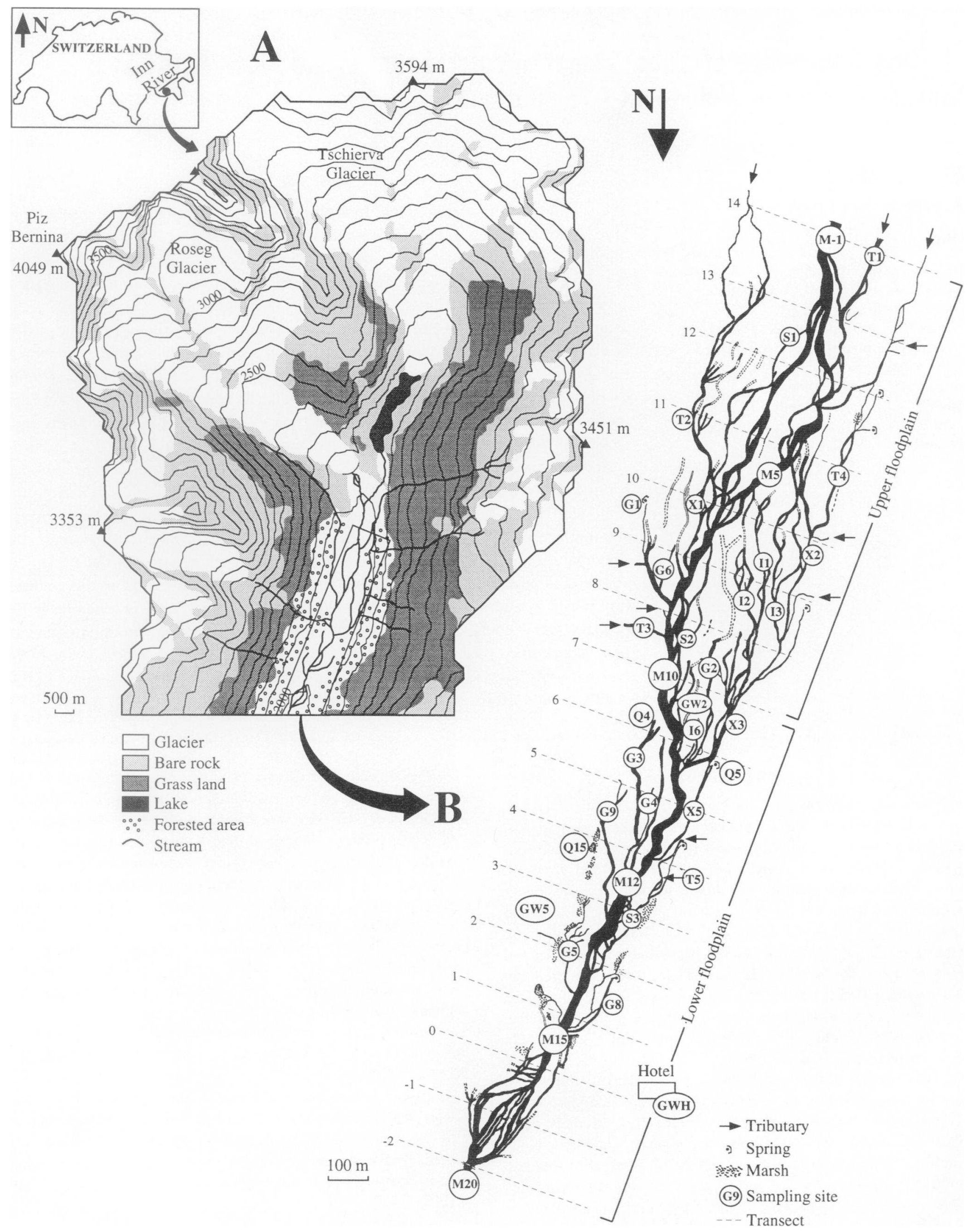

FIGURE 1. A. Topographical map of the upper catchment of the Roseg River. B. Detailed map of the floodplain showing the location of sampling sites. 
snow (Spreafico et al., 1992). Forty-two percent of the area is glaciated. The main glaciers (Tschierva: $6.2 \mathrm{~km}^{2}$; Roseg: 8.5 $\mathrm{km}^{2}$ ) have experienced a continuous retreat (ca. $1100 \mathrm{~m}$ ) during the last $120 \mathrm{yr}$ (Maisch, 1988). The valley slopes are covered by extensive moraine deposits and alluvial fans. Exposed rock materials and rock-soil complex supporting herbaceous vegetation cover 35 and $19 \%$ of the catchment, respectively. Soils developed from glacial till are typically acidic podsols ( $\mathrm{pH} 4$ to 5) that extend to a depth of $30 \mathrm{~cm}$. Subalpine forests $(4 \%)$ are restricted to the lateral sides of the valley, with larch (Larix decidua) and arve pine (Pinus cembra) predominant. The Bernina region belongs to the tectonic formation of the austroalpine and penninikum nappes. Lithologic units in the upper Val Roseg catchment belong to the Err-Bernina and Sella series and are composed exclusively of crystalline rocks. Bedrock on the westfacing slope consists of gabbrodiorite, diorite, and calc-alkaline granite and the east-facing slope is underlain by hornblende granite, mylonitic granite, and monzonite (Staub, 1946; Christ et al., 1964).

The floodplain is $2.6 \mathrm{~km}$ long and covers an area of 0.67 $\mathrm{km}^{2}$ (Fig. 1B). Morphologically, two sections are distinguished (Tockner et al., 1997): a lower section (transects -2 to 7) ranging between 130 and $260 \mathrm{~m}$ in width, and an upper section (transects 7 to 14) that is up to $510 \mathrm{~m}$ wide. The upper section has a steeper slope $(4.8 \%)$ than the lower section (1.9\%). About $40 \%$ of the floodplain is composed of unstable gravels with sparse pioneer plants (dominant species: Epilobium fleischerii, Rumex scutatus, Trifolium repens). Several observations indicate that glaciofluvial deposits extend to a depth of at least $30 \mathrm{~m}$. Preliminary investigations with ground penetrating radar indicated unconsolidated sediment to a depth of at least $30 \mathrm{~m}$ at transects 1 , 5, and 11 (P. Huggenberger, unpublished data). Moreover, two 30-m-deep wells which provide drinking water for the Val Roseg Hotel (site GWH in Fig. 1B) did not reach bedrock. Here, the configuration of valley sides indicate an aquifer depth that may exceed $40 \mathrm{~m}$.

The floodplain contains a diverse array of aquatic habitats, dominated by seven distinct channel types (Tockner et al., 1997; Ward et al., 1999a): the main channel (code M in Fig. 1B), side channels (S), intermittently-connected channels (I), mixed channels $(X)$, groundwater channels $(\mathrm{G})$, springs $(\mathrm{Q})$, and tributaries (T). Floodplain terraces (1- to 2-m high) harbor marshes fed by hillslope aquifers. Most meltwater from the glaciers along the sides of the valley disappears in the morainic and glaciofluvial deposits of the valley slopes. Therefore, all tributaries joining the floodplain, except $\mathrm{T} 1$ and $\mathrm{T} 3$, originate as groundwater fed streams at different elevations on the valley slopes.

The Roseg River is a $11.5-\mathrm{km}$-long second-order stream. Discharge is continuously recorded by the Swiss Hydrological Geological Survey $7.2 \mathrm{~km}$ downstream from the floodplain terminus. The hydrograph is typical of a glacial-melt dominated river, having a distinct seasonal flow regime and marked daily fluctuations in flow during the major ablation period. Mean annual discharge for the period 1955-1994 was $2.8 \mathrm{~m}^{3} \mathrm{~s}^{-1}$; mean discharge in 1996 and 1997 was 2.5 and $3.1 \mathrm{~m}^{3} \mathrm{~s}^{-1}$, respectively.

\section{Materials and Methods}

\section{MAPPING OF THE CHANNEL NETWORK}

The exact position, length, depth, and wetted width of individual channels, springs and marshes were measured in July 1996 along 17 transects (150-200 m apart) perpendicular to the longitudinal axis of the floodplain (Fig. 1B). In addition, aerial photographs (color images and IR-images, spatial resolution: 0.1 m) were taken on 3 September 1996 from a helicopter at $500 \mathrm{~m}$ above ground level. The field measurements and aerial photographs were combined to produce a detailed channel map of the study area. Subsequent changes in the channel pattern were recorded during 15 field surveys carried out from August 1996 to January 1998. Maps were digitized to calculate the total channel length on each sampling date.

\section{SURFACE WATER SAMPLING AT SELECTED SITES}

Site selection was based on (1) obtaining samples from all the major channel types, and (2) having a network of sites distributed all over the floodplain (Fig. 1B). Because of seasonal changes in the extent of the channel network, the number of sampling sites varied from 9 in winter to 33 in summer. During the ablation period, all samples were collected from $0600 \mathrm{~h}$ to $0900 \mathrm{~h}$ in order to avoid changes in water chemistry associated with daily discharge fluctuations. Water was collected in 1-L polyethylene bottles, filtered (Whatman GF/F filters; $0.7 \mu \mathrm{m}$ ) within 1 to $4 \mathrm{~h}$, and stored for 1 to $3 \mathrm{~d}$ at $4^{\circ} \mathrm{C}$ prior to analysis. Specific conductance was measured in the field with a specific conductance meter (WTW LF 323-B/Set; reference temperature $20^{\circ} \mathrm{C}$ ). The $\mathrm{pH}$ was also measured in the field (Orion model $230 \mathrm{~A} \mathrm{pH}$ meter) on a $40 \mathrm{ml}$ aliquot of unfiltered water after adjusting the ionic strength with pHix (Orion).

\section{SNOW AND GROUNDWATER SAMPLING}

From November 1996 to May 1997, the snowpack was sampled by digging pits to ground level and collecting depthintegrated snow samples ( 6 dates, $n=18$ ) in a 3 -L polyethylene bottle. The snow $10 \mathrm{~cm}$ above the ground surface was not sampled to avoid possible contamination from soils or overland flow. Because the snow/water equivalence of the samples was not determined, ion concentrations are reported as microequivalents per liter of snow-melt water $\left(\mu \mathrm{eq} \mathrm{L}^{-1}\right)$.

In July, August, and September 1997, groundwater samples were collected with a peristaltic pump from two PVC piezometers that extended to a depth of $1.4 \mathrm{~m}$ below the water table. Piezometer GW2 was located at transect 7 in the middle of the floodplain, while piezometer GW5 was installed close to transect 1 in a meadow located on the right side of the floodplain (Fig. 1B). On 28 February 1998, groundwater was collected from a 30-m-deep well (site GWH) at the Val Roseg Hotel. Water collected from these three sites is referred as shallow alluvial groundwater (site GW2), hillslope groundwater (site GW5) and deep alluvial groundwater (site GWH).

\section{SAMPLE ANALYSIS}

Calcium, magnesium, sodium, and potassium were analyzed with an Inductively Coupled Plasma-Optical Emission Spectrometer (SPECTRO Analytical Instruments, Kleve, Germany). Silica was determined by the heteropoly blue method (APHA, 1989). Sulfate was determined spectrophotometrically by the turbidimetric method (APHA, 1989). Bicarbonate determination was made by $\mathrm{CO}_{2}$ detection (Horiba IR-detector) after samples had been acidified and heated to $860^{\circ} \mathrm{C}$. Ammonium was measured with the indophenol-blue method. Nitrite was measured by spectrophotometry after diazotizing with sulfanilamide and coupling with N-(1-naphthyl)-ethylenediamine (Rodier, 1996). Nitrate was determined with the automated hydrazine reduction method (Downes, 1978). The same method was 
used to determine total dissolved nitrogen (TDN) after all nitrogen forms had been oxidized to nitrate with $\mathrm{K}_{2} \mathrm{~S}_{2} \mathrm{O}_{8}$ at $121^{\circ} \mathrm{C}$ (Ebina et al., 1983). Dissolved organic nitrogen (DON) was then calculated as the difference between TDN and inorganic forms of nitrogen (ammonium, nitrite, and nitrate). Dissolved oxygen was measured with the Winkler method.

Quality assurance of chemical analyses was based on a subset of 247 water samples. First, there was a strong linear correlation $\left(y=21.5 x+1.84 ; r^{2}=0.97\right)$ between the sum of charge equivalents $\left(y\right.$ in $\mu \mathrm{eq} \mathrm{L}^{-1}$ ) and specific conductance ( $x$ in $\left.\mu S \mathrm{~cm}^{-1}\right)$. Second, the average charge balance error for these 247 water samples was $\pm 4.3 \%(\mathrm{SD}=3$; $\min .=0$; $\max$. $=$ 13.3). Third, we calculated the specific conductance of each water sample from the ion analyses utilizing the appropriate diluted-conductance factor for the various ions (Rodier, 1996). The linear regression between the calculated specific conductance $(y)$ and measured specific conductance was $y=1.02 x-2.02\left(r^{2}\right.$ $=0.97$ ). Student's test indicated that the slope of the line was not statistically different from 1 and the elevation did not differ significantly from 0 .

\section{DATA ANALYSIS}

One-way ANOVA followed by Tukey's multiple comparison test was used to compare differences in ion concentrations among dates for all sites combined. When necessary, data were Log (concentration) or Arcsine (molar ratio) transformed to meet the assumption of normality and homogeneity of variance. Differences between concentrations are considered significant when $P<0.05$. For each sampling date, ion concentrations of the sampling sites were plotted directly on a floodplain map using circles, the surface area of which was proportional to the concentration (GraphMu software; Thioulouse, 1989). To facilitate the reading of a map, circles were further differentiated by shading. Each shading pattern corresponds to an ion concentration range that was determined by a 4-mean clustering analysis performed on all water samples collected during the sampling period.

\section{Results}

\section{SPATIO-TEMPORAL CHANGES IN THE TOTAL LENGTH OF THE CHANNEL NETWORK}

The channel network showed a distinct seasonal expansion/ contraction cycle (Fig. 2). Channel disappearance as indicated in Figure 2 was due to drying and not snow cover. The total length of active channels ranged from $5.9 \mathrm{~km}$ on 27 January $1998(Q$ $\left.=0.1 \mathrm{~m}^{3} \mathrm{~s}^{-1}\right)$ to $21.4 \mathrm{~km}$ on 2 September $1997\left(Q=5.9 \mathrm{~m}^{3}\right.$ $\mathrm{s}^{-1}$ ). Channel contraction was much more pronounced in the upper part of the floodplain (transects 7 to 14). On an annual basis, the maximum reduction in total channel length was $36 \%$ in the lower floodplain versus $92 \%$ in the upper floodplain. In this latter area, channel contraction did not follow a simple upstream/ downstream pattern (Fig. 2). Two phases were apparent. In the first phase (2 Sept.-14 Dec. 1997), most side channels and the upstream ends of channels located between transects 8 and 11 lost all surface water. This phase was rapid and resulted in the surface disconnection between the channel networks of the upper and lower floodplains. During the second phase (14 Dec. 199727 Jan. 1998) further reduction of the total channel length was due mainly to the progressive drying of the upstream part of the channel network (between transects 6 and 8). The expansion cycle (2 Feb.-7 June 1997) followed a similar pattern, the different phases being simply reversed in time (Fig. 2).
The total channel length and mean specific conductance for the floodplain (mean of all sites) were significantly correlated with discharge (Fig. 3A). However, the relationship was typically not linear, the slope of the lines being much steeper for discharge values below $1.5 \mathrm{~m}^{3} \mathrm{~s}^{-1}$, and the curves were not symmetric (Fig. 3B). Indeed, the slope of the regression line between specific conductance and channel length was statistically different from -1 . This asymmetry was due only to differences in specific conductance that were measured during the expansion and contraction cycles. For a given discharge value, the total channel length during the expansion and contraction phases was similar, but the average specific conductance was always higher during the expansion phase.

\section{PHYSICO-CHEMICAL CHARACTERISTICS OF SNOW-MELT WATER, GLACIAL WATER, AND GROUNDWATER}

\section{Snow-melt Water}

The physico-chemical composition of different water sources is listed in Table 1. While snow samples collected from November 1996 to February 1997 were extremely dilute (average specific conductance $=2.8 \mu \mathrm{S} \mathrm{cm} \mathrm{cm}^{-1} ; \mathrm{SD}=0.8 ; n=12$ ), those collected in March and April 1997 were enriched in $\mathrm{Ca}^{2+}$ and $\mathrm{HCO}_{3}{ }^{-}$and had a relatively high specific conductance (up to 14 $\mu \mathrm{S} \mathrm{cm}{ }^{-1}$ ) (Table 1). Snowpack samples at the end of the accumulation period had a high total nitrogen concentration (TDN) of $27 \mu \mathrm{eq} \mathrm{L}{ }^{-1} \mathrm{~N}$, of which 11,41 , and $48 \%$ were $\mathrm{NH}_{4}{ }^{+}, \mathrm{NO}_{3}{ }^{-}$ and dissolved organic nitrogen (DON), respectively. The relative contribution of different nitrogen forms to TDN in surface water samples collected in April and May $(n=41)$ was markedly different from those measured in the snowpack. $\mathrm{NO}_{3}{ }^{-}$was the dominant species $(87 \%)$ in surface water, DON represented only $12 \%$ of TDN and $\mathrm{NH}_{4}{ }^{+}$was below detectable levels in most samples $\left(<1 \mu\right.$ eq $\left.\mathrm{L}^{-1} \mathrm{~N}\right)$. Sulfate concentrations in the snow pack were highly variable, ranging from nondetectable levels to $40 \mu \mathrm{eq} \mathrm{L} \mathrm{L}^{-1}$. Sodium, potassium, and silica concentrations were in most cases below detectable levels.

\section{Glacial Water}

Glacial water collected at site M-1 during the ablation period also had a low specific conductance (Table 1). Its chemical composition was characterized by high relative abundances of $\mathrm{Ca}^{2+}$ and $\mathrm{HCO}_{3}{ }^{-} \cdot \mathrm{Ca}^{2+}$ concentrations in glacial water accounted for $86 \%$ of the cations and the $\mathrm{SO}_{4}{ }^{2-} / \mathrm{HCO}_{3}{ }^{-}$ratio was distinctly lower than that measured in shallow alluvial groundwater (site GW2), and hillslope groundwater (site GW5).

\section{Groundwater}

Ion concentrations (except $\mathrm{NO}_{3}{ }^{-}$) were markedly higher in groundwater than in glacial water, but there were great differences in the chemical composition of the different types of groundwater. Ion concentrations, except nitrogen forms, increased in the following order: shallow alluvial groundwater (site GW2), hillslope groundwater (site GW5) and deep alluvial groundwater (site GWH). Dissolved oxygen showed a reverse trend. Reducing conditions in deep alluvial groundwater were indicated by the absence of oxygen, the lack of nitrate and a lower $\mathrm{SO}_{4}{ }^{2-}$ concentration. The increase in concentrations among the different types of groundwater was not proportional for all ions. In particular, the $\mathrm{Na}^{+} / \mathrm{Ca}^{2+}$ ratio was markedly lower in shallow alluvial groundwater than in hillslope and deep alluvial groundwaters. Inversely, the relative proportion of $\mathrm{HCO}_{3}{ }^{-}$ 


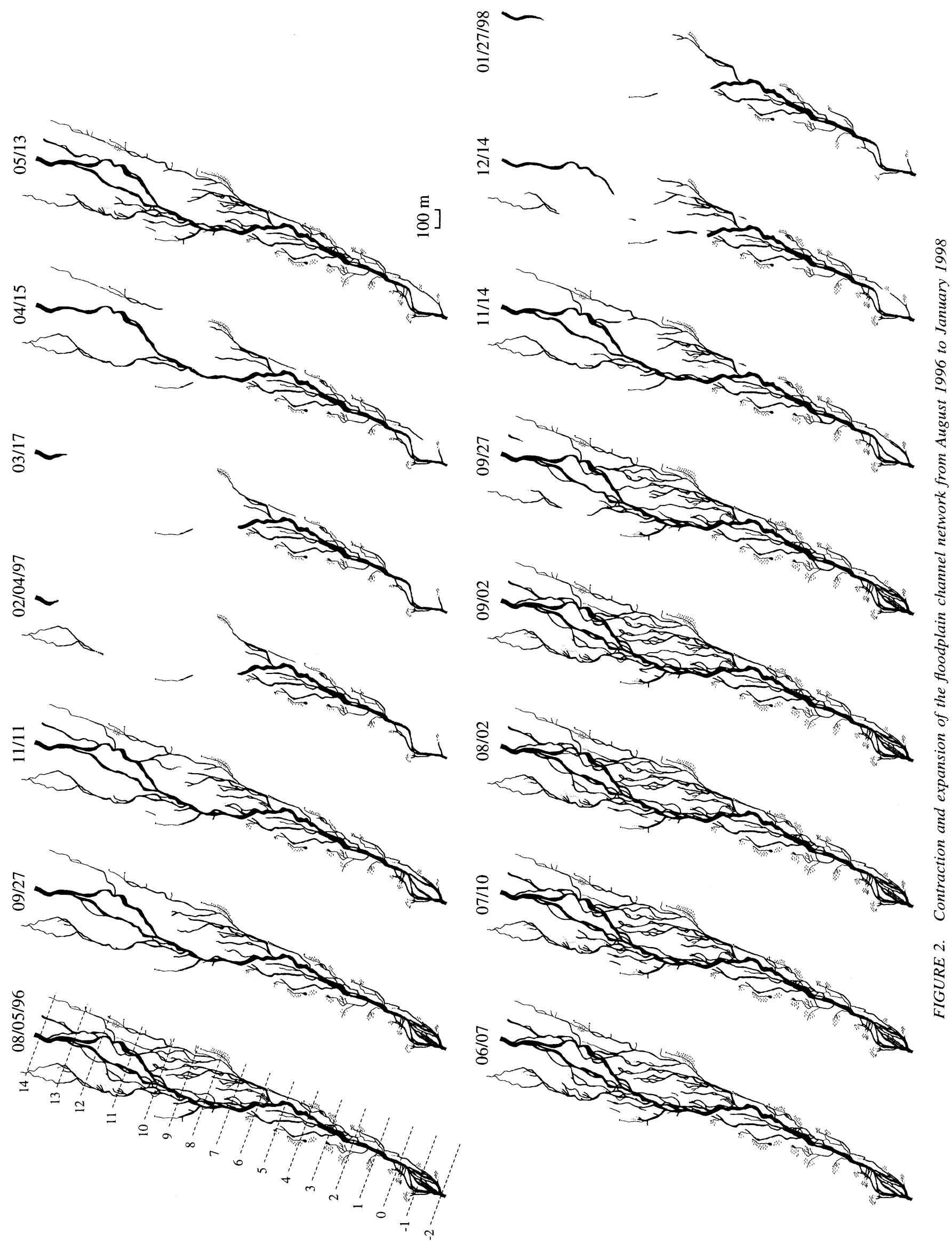

F. MALARD ET AL. / 139 


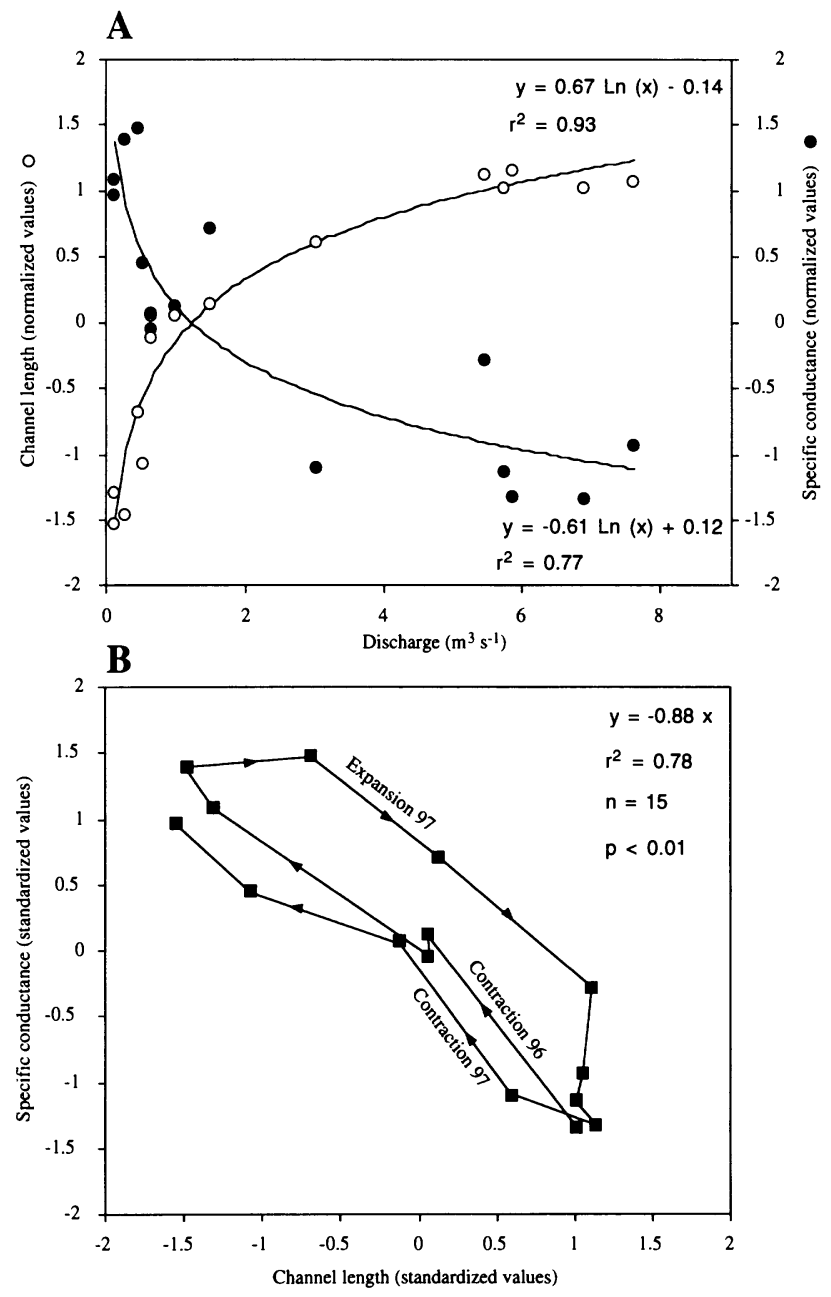

FIGURE 3. A. Plots of total channel length and specific conductance for the floodplain (i.e. average of specific conductance of all sampling sites) versus river discharge. B. Plot of specific conductance versus total channel length. Values of the specific conductance and channel length were standardized $(Z=(X-\mu) / \sigma)$.

to $\mathrm{SiO}_{2}$ was higher at site GW2 (shallow alluvial groundwater) than at sites GW5 (hillslope groundwater) and GWH (deep alluvial groundwater)

\section{TEMPORAL CHANGES IN ION CONCENTRATIONS OF SURFACE WATER}

Temporal changes in the average concentration of major ions are shown in Figure 4. Three different seasonal patterns are apparent. Specific conductance, $\mathrm{pH}, \mathrm{Ca}^{2+}, \mathrm{Mg}^{2+}, \mathrm{HCO}_{3}{ }^{-}$, and $\mathrm{SO}_{4}{ }^{2-}$ exhibited a pronounced seasonal variability with high values in winter and low values during the ablation period. Average ion concentrations were inversely related to discharge. However, the best coefficients of determination $\left(r^{2}=0.58\right.$ to 0.87$)$ were obtained with logarithmic regressions similar to that presented for specific conductance (Fig. 3A). For similar discharge values, ion concentrations during the rising limb of the hydrograph were higher than those measured during the declining limb. For example, $\mathrm{Ca}^{2+}$ concentrations in April $\left(832 \mu \mathrm{eq} \mathrm{L} \mathrm{L}^{-1} ; Q=0.5 \mathrm{~m}^{3}\right.$ $\left.\mathrm{s}^{-1}\right)$ and May (725 $\left.\mu \mathrm{eq} \mathrm{L}^{-1} ; Q=1.5 \mathrm{~m}^{3} \mathrm{~s}^{-1}\right)$ were higher than those measured in November $1996\left(625 \mu \mathrm{eq} \mathrm{L}^{-1} ; Q=0.7 \mathrm{~m}^{3}\right.$ $\left.\mathrm{s}^{-1}\right)$ and November 1997 (621 $\left.\mu \mathrm{eq} \mathrm{L} \mathrm{L}^{-1} ; Q=0.7 \mathrm{~m}^{3} \mathrm{~s}^{-1}\right)$

Average concentrations of $\mathrm{Na}^{+}$and $\mathrm{SiO}_{2}$ also exhibited a winter/summer shift. However, the standard deviation was al- ways high, indicating that the spatial effect was more important than the temporal effect in explaining the variability of these parameters. Because of their high spatial heterogeneity, multiple comparison tests applied to average concentrations failed to detect significant differences among dates. Potassium concentrations also increased in winter; however, concentrations were below $10 \mu \mathrm{eq} \mathrm{L}^{-1}$ for most of the sites and dates. Higher average concentrations in June, September, December, and January were mainly attributable to extremely high values (from 20 to $80 \mu \mathrm{eq}$ $\mathrm{L}^{-1}$ ) measured at particular sites.

Nitrate was the only parameter that did not have a "winter high" versus "summer low" concentration cycle. Concentrations peaked in March, April, May, and June. During these 4 mo, the average $\mathrm{NO}_{3}{ }^{-}$concentration of surface water (25 to 29 $\mu$ eq $\mathrm{L}^{-1}$ ) was similar to the total nitrogen content of the snowmelt water $\left(27 \mu \mathrm{eq} \mathrm{L}^{-1} \mathrm{~N}\right)$. Average $\mathrm{NO}_{3}{ }^{-}$concentration was weakly correlated to discharge $(r=-0.24)$. From March to June, there was little change in the average concentration, despite an 18-fold increase in discharge (from 0.3 to $5.5 \mathrm{~m}^{3} \mathrm{~s}^{-1}$ ) and a pronounced decrease in the concentrations of other ions.

\section{SPATIAL DISTRIBUTION OF ION CONCENTRATIONS IN SURFACE WATER}

Changes in the spatial pattern of concentrations over the whole hydrological cycle are presented only for $\mathrm{Ca}^{2+}, \mathrm{SiO}_{2}$, and $\mathrm{NO}_{3}{ }^{-}$(Figs. 5, 6, 7). These parameters best illustrate changes in the spatial heterogeneity that correspond to each of the three different temporal patterns described above.

The greatest difference in $\mathrm{Ca}^{2+}$ content among the floodplain water bodies was observed from 2 August to 27 September (Fig. 5). The $\mathrm{Ca}^{2+}$ concentration increased with decreasing surface or subsurface hydrological connectivity with the main channel. The lowest concentrations were measured in the main stem of the river, in channels having an upstream connection with the main channel, and in tributaries fed by secondary glaciers (i.e. sites $\mathrm{T} 1, \mathrm{~T} 3, \mathrm{~T} 4)$. The $\mathrm{Ca}^{2+}$ content of water was higher in groundwater channels located within (i.e. sites G2, G4) and outside the active floodplain (i.e. sites G1, G5, G8), and in tributaries fed by groundwater (i.e. sites T2, T5). Differences in $\mathrm{Ca}^{2+}$ concentrations among sites were attenuated in November and a rather homogeneous pattern emerged in February, March, April, May, December, and January (Fig. 5). Spatial patterns in $\mathrm{Ca}^{2+}$ concentrations were virtually identical in April and December. On both dates, water at site $\mathrm{M}-1$ was enriched in $\mathrm{Ca}^{2+}$ and concentrations were relatively uniform along the longitudinal dimension. Specific conductance, $\mathrm{HCO}_{3}{ }^{-}, \mathrm{Mg}^{2+}$, and to a lesser extent $\mathrm{SO}_{4}{ }^{2-}$ all showed spatial patterns similar to calcium during the ablation period.

During the ablation period, $\mathrm{SiO}_{2}$ was distinctly higher at sites located in the floodplain margins (Fig. 6). In contrast to $\mathrm{Ca}^{2+}, \mathrm{SiO}_{2}$ concentrations were high in all tributaries, including those fed by glaciers along the side of the valley (i.e. sites $\mathrm{T} 1$, T3, T4). Groundwater channels located in the active floodplain were not markedly enriched in $\mathrm{SiO}_{2}$ (i.e. sites G2, G4). Such a spatial pattern persisted over time although it was attenuated in winter due to an increase in the $\mathrm{SiO}_{2}$ concentration of water in the active floodplain. The spatial patterns in concentrations during the expansion and contraction phases differed markedly (Fig. 6). During the expansion phase in $\mathrm{April}, \mathrm{SiO}_{2}$ concentrations in the active floodplain were relatively uniform along the longitudinal dimension, whereas in December most of the sites located in the upper floodplain had lower concentrations than those located in the lower floodplain. Difference between the distribu- 


\begin{tabular}{|c|c|c|c|c|c|c|c|c|c|}
\hline & \multicolumn{2}{|c|}{$\begin{array}{c}\text { Snow } \\
n=6^{b}\end{array}$} & \multicolumn{2}{|c|}{$\begin{array}{l}\text { Glacial water } \\
\text { (site } M-1 \text { ) } \\
\text { n }=3\end{array}$} & \multicolumn{2}{|c|}{$\begin{array}{l}\text { Shallow alluvial } \\
\text { ground water } \\
\text { (site GW2) } \\
n=3\end{array}$} & \multicolumn{2}{|c|}{$\begin{array}{l}\text { Ground water } \\
\text { Hillslope } \\
\text { ground water } \\
\text { (site GW5) } \\
\text { n }=3\end{array}$} & \multirow{2}{*}{$\begin{array}{c}\text { Deep alluvial } \\
\text { ground water } \\
\text { (site GWH) } \\
\text { n }=1\end{array}$} \\
\hline & $\overline{\mathbf{x}}$ & SD & $\overline{\mathbf{x}}$ & SD & $\overline{\mathrm{x}}$ & SD & $\overline{\mathbf{x}}$ & SD & \\
\hline $\mathrm{NH}_{4}^{+}$ & 3 & 1 & 1 & 0 & nd & nd & nd & nd & 36 \\
\hline $\mathrm{NO}_{3}^{-}$ & 11 & 1 & 16 & 2 & 9 & 1 & 18 & 2 & 1 \\
\hline DON & 13 & 6 & 2 & 2 & 2 & 3 & 2 & 2 & nd \\
\hline $\mathrm{Ca}^{2+}$ & 80 & 30 & 328 & 55 & 681 & 115 & 898 & 27 & 893 \\
\hline $\mathbf{M g}^{2+}$ & 6 & 2 & 39 & 8 & 63 & 10 & 118 & 2 & 259 \\
\hline $\mathrm{Na}^{+}$ & nd & nd & 10 & 4 & 24 & 6 & 79 & 1 & 135 \\
\hline $\mathrm{K}^{+}$ & nd & nd & 4 & 4 & 10 & 1 & 12 & 2 & 30 \\
\hline $\mathrm{HCO}_{3}^{-}$ & 99 & 31 & 292 & 58 & 583 & 58 & 766 & 52 & 1107 \\
\hline $\mathrm{SO}_{4}^{2-}$ & 14 & 15 & 55 & 28 & 147 & 66 & 279 & 25 & 110 \\
\hline $\mathrm{SiO}_{2}$ & nd & nd & 20 & 5 & 46 & 1 & 100 & 1 & 300 \\
\hline Sp. cond. & 10.1 & 3.1 & 34.6 & 5.8 & 66.0 & 10.9 & 95.3 & 1.4 & 114.2 \\
\hline $\mathrm{pH}$ & - & - & 6.68 & 0.08 & 6.77 & 0.19 & 6.76 & 0.21 & - \\
\hline DO & - & - & 331 & 12 & 256 & 3 & 175 & 3 & 3 \\
\hline
\end{tabular}

nd: non detectable

-: not measured

${ }^{a}$ See Figs. 5, 6, and 7 for replication. All concentrations are in $\mu$ eq $\mathrm{L}^{-1}$ except $\mathrm{SiO}_{2}$ and dissolved oxygen (DO) in $\mu$ mol $\mathrm{L}^{-1}$ and specific conductance (Sp. cond.) in $\mu \mathrm{S} \mathrm{cm}^{-1}$. Snow samples were collected in March and April 1997. Glacial water, shallow alluvial groundwater, and hillslope groundwater were sampled during the ablation period (from July to September 97) at sites M-1, GW2, and GW5, respectively (see Fig. 1B). Deep alluvial groundwater was sampled on 28 February 1998 from a 30-m deep well (site GWH in Fig. 1B).

b 18 samples were taken but only these 6 relate to the end of the snow accumulation period

tional patterns of concentrations during the expansion and contraction phases also was observed for specific conductance, $\mathrm{HCO}_{3}{ }^{-}, \mathrm{Mg}^{2+}$, and $\mathrm{Na}^{+}$.

Although there were significant temporal changes in the average $\mathrm{NO}_{3}{ }^{-}$content of floodplain water, concentrations were relatively uniform across space on most dates (Fig. 7). Thus, in contrast to $\mathrm{SiO}_{2}$, a temporal effect was more important than a spatial effect in explaining the variability in $\mathrm{NO}_{3}{ }^{-}$.

\section{SPATIO-TEMPORAL CHANGES IN THE RELATIVE ABUNDANCES OF IONS}

Figure $8 \mathrm{~A}$ shows a plot of the molar ratio of $\mathrm{Na}^{+} / \mathrm{Ca}^{2+}$ versus the molar ratio of $\mathrm{HCO}_{3}{ }^{-} / \mathrm{H}_{4} \mathrm{SiO}_{4}$ for all surface water samples collected from March to January. In most cases, sites located on the floodplain margins had a higher $\mathrm{Na}^{+} / \mathrm{Ca}^{2+}$ ratio and a lower $\mathrm{HCO}_{3}-\mathrm{H}_{4} \mathrm{SiO}_{4}$ ratio than those located in the active part of the floodplain (Fig. 8A). The water sample from site GWH (deep alluvial groundwater) plots at the top of the cluster of data points. Such a spatial differentiation of sampling sites was observed despite great differences in the specific conductance among sites located on the floodplain margins. In July, water samples collected at sites G1, G5, T3, T4, and X5 had similar high $\mathrm{Na}^{+} / \mathrm{Ca}^{2+}$ ratios $(0.17$ to 0.22$)$, but the specific conductance among these sites varied widely ( 24.8 to $91.8 \mu \mathrm{S} \mathrm{cm}^{-1}$ ).

Seasonal changes in the average $\mathrm{Na}^{+} / \mathrm{Ca}^{2+}$ ratio of sites located within and outside the active floodplain are indicated in Figure 8B. No significant difference was observed among dates for sites located on the floodplain margins. In contrast, the ratio at sites located within the active floodplain tended to increase from summer to winter. The average $\mathrm{Na}^{+} / \mathrm{Ca}^{2+}$ ratio on 2 September 1997 was significantly higher than those measured in February, March, and January. The increase in the $\mathrm{Na}^{+} / \mathrm{Ca}^{2+}$ ra- tio of surface water also was more pronounced in the downstream end of the floodplain (e.g. sites M12, S3, M15 and M20).

The average $\mathrm{SO}_{4}{ }^{2-} / \mathrm{HCO}_{3}{ }^{-}$of sites also differed significantly among dates (Fig. $8 \mathrm{C}$ ). The relative abundance of $\mathrm{SO}_{4}{ }^{2-}$ to $\mathrm{HCO}_{3}{ }^{-}$decreased markedly towards the summer; this temporal trend being observed for sites located within and outside the active floodplain. The decrease in the $\mathrm{SO}_{4}{ }^{2-} / \mathrm{HCO}_{3}{ }^{-}$ratio was abrupt in spring (from April to June), whereas the increase was more gradual in autumn (27 Sept.-14 Dec.).

\section{Discussion}

\section{EXPANSION AND CONTRACTION CYCLE OF THE CHANNEL NETWORK}

The expansion and contraction cycle of the channel network is controlled by seasonal changes in catchment discharge. However, there is a threshold value in discharge (i.e. $1.5 \mathrm{~m}^{3} \mathrm{~s}^{-1}$ ) above which the length of the stream network is less sensitive. Moreover, differences in the seasonal fluctuations of the total channel length between the upper and lower floodplain are not related to discharge but rather to surface water-groundwater exchanges. Along the longitudinal dimension, there is a net downwelling of surface water at the upper end of the floodplain and a net upwelling of groundwater at the downstream end (Ward et al., 1999a). Such a downwelling-upwelling flow pattern is due to a combination of factors including a marked decrease in floodplain slope and narrowing of the valley at transect 7 , a further narrowing downstream at transect -2 , and a continuous decline in sediment size downvalley that may result in a decrease in permeability (Tockner et al., 1997).

De Vries (1995) showed that stream density in shallow aquifer systems was related to the depth of the groundwater table 
and position and incision depth of the drainage channels. However, seasonal fluctuations of the groundwater table cannot be the only hydrological process influencing stream density in the upper floodplain of the Val Roseg. Channel contraction in autumn was occurring too rapidly to result from a progressive downward movement of the groundwater table. Second, a decline in the groundwater table should result in a progressive upstream/downstream pattern of contraction of surface waters. This pattern was not observed in autumn because the surface flows in the upper and lower floodplains were disconnected.

Differences between the seasonal pattern of expansion and contraction in the upper and lower floodplains of the Val Roseg are more likely due to downstream changes in hydraulic connections between surface water and groundwater. In the lower floodplain, streams are hydraulically connected with groundwater through water-saturated sediments (Malard et al., in press). In contrast, most channels behave as perched streams in the upper floodplain at least during autumn, because they have their bed surface above the groundwater table. Thus, drying occurs rapidly (Nov.-Dec.) when surface water flow is too low to compensate for water infiltration through unsaturated and highly permeable sediments. Further reduction in the lower floodplain channel network (Dec.-Jan.) is more gradual and follows an upstream/downstream pattern that closely corresponds to a progressive decline of the groundwater table. Downstream changes in the type of hydraulic connections between streams and alluvial groundwater have already been observed in floodplain systems of the Flathead River, Montana (Stanford and Ward, 1993) and Tagliamento River, Italy (Ward et al., 1999b). This is likely to be a common hydraulic feature of montane and piedmont valley floodplains where steep gradient rivers enter flat areas consisting of extensive alluvium. In a 3-mo study of surface water distribution along a $12-\mathrm{km}$ section of a desert stream, drying started in the center of the largest unconstrained section and progressed in both upstream and downstream directions, surface water flow finally being restricted to constrained sections (Stanley et al., 1997).

\section{PHYSICO-CHEMICAL FINGERPRINTS OF WATER SOURCES AND FLOW PATHS}

\section{Specific Conductance and Solute Concentration}

Specific conductance and concentrations of dissolved solids is related to the source and flow paths of water entering the floodplain. Dilute water (e.g. specific conductance $<10 \mu \mathrm{S} \mathrm{cm}^{-1}$ ) is generated by the melting of snow and ice. Meltwater is then enriched in solutes as it comes into contact with rock materials of the catchment. There is only a limited increase in dissolved solids when flow occurs on the surface of the glacier (i.e. supraglacial water), in the channelized system of the glacier (i.e. englacial water), on the land surface (overland flow) and in surface channels (stream flow). In contrast, solute enrichment is promoted during flow of water in the distributed drainage system beneath the glacier (i.e. subglacial water) and within subsurface reservoirs of the catchment (e.g. shallow alluvial groundwater, hillslope groundwater, and deep alluvial groundwater).
The $\mathrm{Na}^{+} / \mathrm{Ca}^{2+}$ and $\mathrm{HCO}_{3}{ }^{-} / \mathrm{H}_{4} \mathrm{SiO}_{4}$ Ratios

A striking characteristic of surface water in the Val Roseg floodplain is its high relative concentration of $\mathrm{Ca}^{2+}$ over $\mathrm{Na}^{+}$and $\mathrm{K}^{+}$and its low relative content of $\mathrm{SiO}_{2}$ over $\mathrm{HCO}_{3}{ }^{-}$. The content of base cations $\left(\mathrm{Ca}^{2+}, \mathrm{Mg}^{2+}, \mathrm{Na}^{+}, \mathrm{K}^{+}\right)$, bicarbonate, and silica of water from silicate rocks is controlled by the stoichiometric alteration of primary minerals (i.e. plagioclase feldspars, biotite and K-feldspar) to well-defined secondary minerals (i.e. kaolinite, smectite) (Garrels, 1967). The alteration of plagioclase, which is usually considered as the main source of $\mathrm{Ca}^{2+}$ and $\mathrm{Na}^{+}$ in water from silicate rocks, should release $\mathrm{Na}^{+}$and $\mathrm{Ca}^{2+}$ to solution in approximately the same ratio as they occur in the rock (equation 1). The same rationale can be applied to the weathering of biotite, that provides $\mathrm{K}^{+}$and $\mathrm{Mg}^{2+}$ in solution (equation 2).

Plagioclase ( $\mathrm{x}=$ mole fraction of anorthite)

$$
\begin{gathered}
\mathrm{Na}_{(1-\mathrm{x})} \mathrm{Ca}_{\mathrm{x}} \mathrm{Al}_{(1+\mathrm{x})} \mathrm{Si}_{(3-\mathrm{x})} \mathrm{O}_{8}+(1+\mathrm{x}) \mathrm{CO}_{2}+1 / 2(11-5 \mathrm{x}) \mathrm{H}_{2} \mathrm{O} \\
\rightarrow 1 / 2(1+\mathrm{x}) \mathrm{Al}_{2} \mathrm{Si}_{2} \mathrm{O}_{5}(\mathrm{OH})_{4}+(1-\mathrm{x}) \mathrm{Na}^{+}+\mathrm{xCa}^{2+} \\
\quad \mathrm{Kaolinite}^{-1} \\
+(1+\mathrm{x}) \mathrm{HCO}_{3}^{-}+2(1-\mathrm{x}) \mathrm{H}_{4} \mathrm{SiO}_{4}
\end{gathered}
$$

Biotite ( $\mathrm{x}=$ mole fraction of magnesium)

$$
\begin{aligned}
& \mathrm{KMg}_{\mathrm{x}} \mathrm{Fe}_{(3-\mathrm{x})} \mathrm{AlSi}_{3} \mathrm{O}_{10}(\mathrm{OH})_{2}+(1+2 \mathrm{x}) \mathrm{CO}_{2}+15 / 2 \mathrm{H}_{2} \mathrm{O}+\mathrm{O}_{2} \\
& \rightarrow \underset{\mathrm{Al}_{2} \mathrm{Si}_{2} \mathrm{O}_{5}(\mathrm{OH})_{4}+\mathrm{K}^{+}+\mathrm{xMg}^{2+}+(1+2 \mathrm{x}) \mathrm{HCO}_{3}^{-}}{ } \quad \mathrm{Kaolinite} \\
& \quad+(3-\mathrm{x}) \mathrm{Fe}(\mathrm{OH})_{2}+2 \mathrm{H}_{4} \mathrm{SiO}_{4}
\end{aligned}
$$

An average $\mathrm{Na}^{+} / \mathrm{Ca}^{2+}$ ratio of 0.12 for surface water in the Val Roseg floodplain would imply that the plagioclase contains only about $10 \%$ albite and $90 \%$ anorthite. Although information on the mineralogical composition of the granite in the Val Roseg catchment is not available, this ratio of anorthite to albite is highly improbable; rather, there must be an additional source of the $\mathrm{Ca}^{2+}$. Anomalously low ratios of $\mathrm{Na}^{+}$to $\mathrm{Ca}^{2+}$ in water from igneous rocks have been reported by several authors (Collins, 1979; Drever and Hurcombs, 1986; Mast et al., 1990; Charles, 1991; Chillrud et al., 1994). In most of these cases, the dissolution of minor amount of calcite present in the bedrock was identified as the most plausible source of $\mathrm{Ca}^{2+}$ (equation 3 ).

$$
\mathrm{CaCO}_{3}+\mathrm{H}_{2} \mathrm{O}+\mathrm{CO}_{2} \rightarrow \mathrm{Ca}^{2+}+2 \mathrm{HCO}_{3}^{-} \text {. }
$$

Assuming little variation in the composition of plagioclase, spatial heterogeneities in the ratios of $\mathrm{Na}^{+} / \mathrm{Ca}^{2+}$ and $\mathrm{HCO}_{3}-1$ $\mathrm{H}_{4} \mathrm{SiO}_{4}$ are likely to reflect differences in the selectivity of chemical weathering that occur under different hydrologic flow paths and residence times of the water (Stallard and Edmond, 1983). Rapid movement of surface water and shallow groundwater in freshly exposed rock materials deposited below the glaciers and within the floodplain may result in selective weathering that favours the preferential dissolution of calcite. In contrast, dissolution of silicate minerals would be enhanced during longer groundwater flow paths in the more weathered rock materials of the valley slopes and deep alluvial aquifers. Drever and Hur-

FIGURE 4. Temporal changes in the river discharge (biweekly average) and solute composition of floodplain water (average and standard deviation of ion concentrations of all sampling sites). Horizontal bars summarize the results of the Tukey's multiple comparison tests used to compare differences in average ion concentrations among dates. Horizontal bars that lie on the same level and overlapping bars represent sampling dates that are not significantly different from each other. 

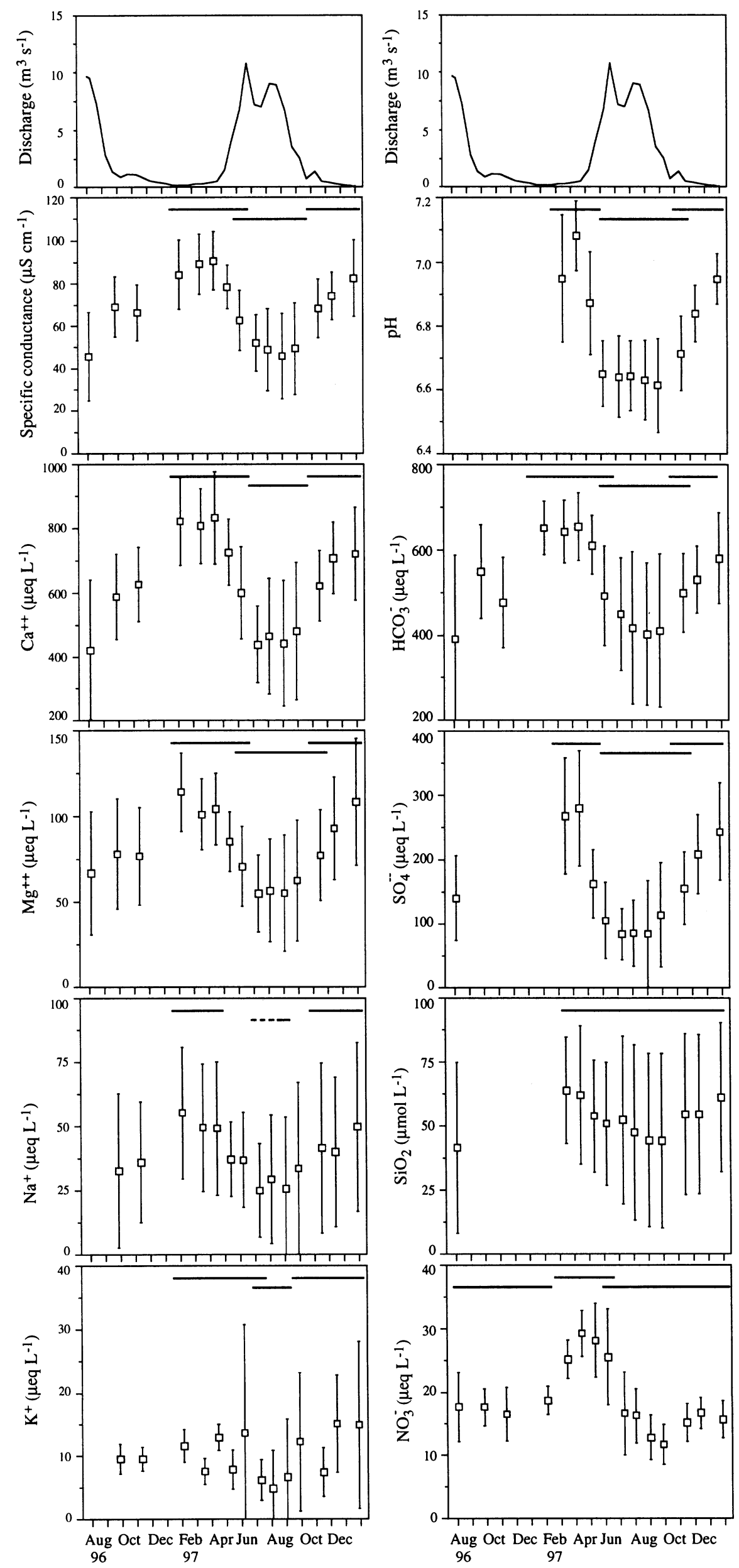

F. MALARD ET AL. / 143

This content downloaded from 152.88.140.154 on Mon, 12 Jun 2017 09:26:09 UTC All use subject to http://about.jstor.org/terms 


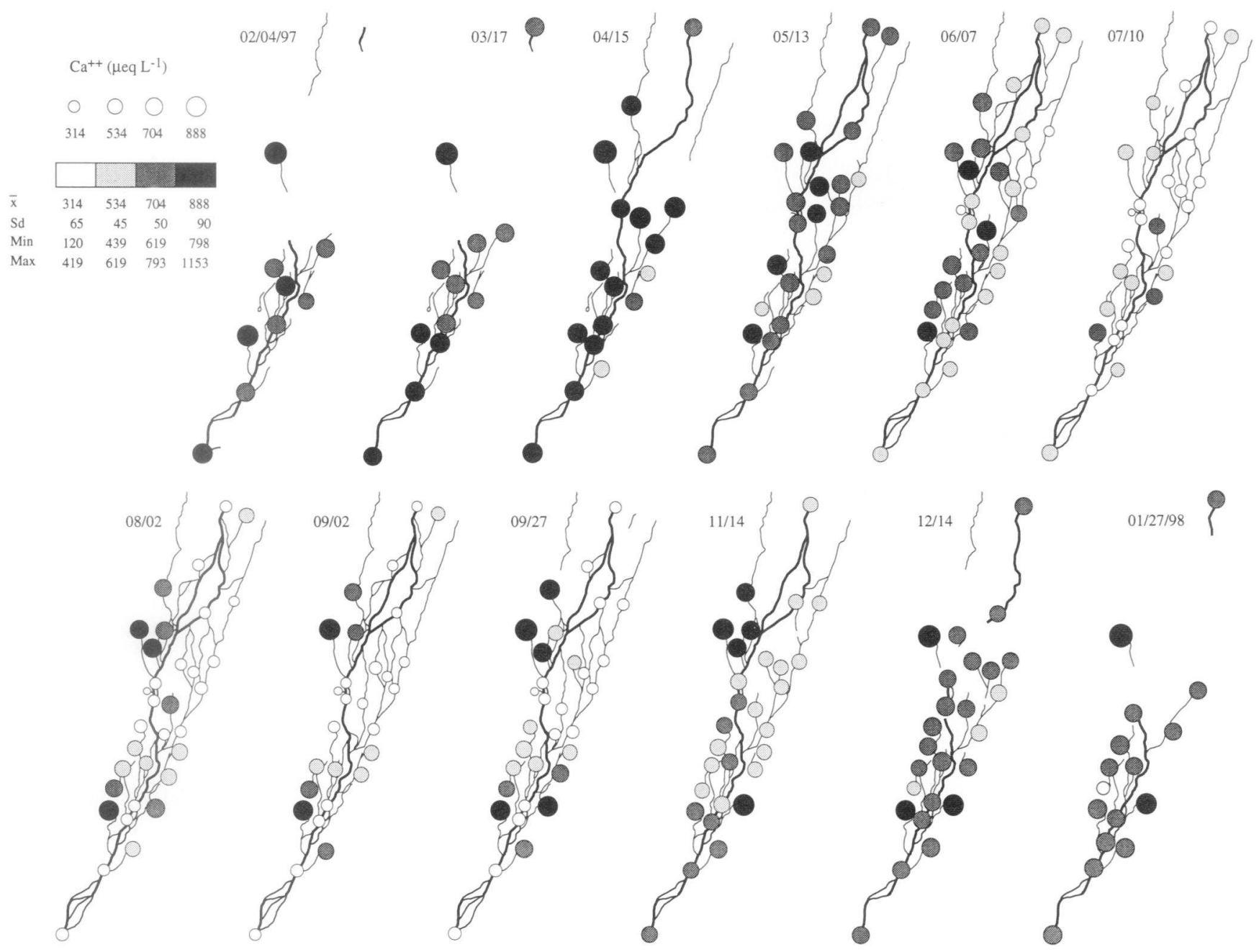

FIGURE 5. Temporal changes in the spatial distribution in $\mathrm{Ca}^{2+}$ concentrations. The surface area of circles is proportional to the chemical concentration and the gray patterns indicate the concentration classes determined by a 4-mean clustering analysis.

comb (1986), Stauffer (1990), and Mast et al. (1990) also suggested that the selective weathering of carbonates in glaciated or recently deglaciated catchments occurred as a result of intensive mechanical erosion that exposed large amounts of fresh bedrock to precipitation. In the absence of intensive physical erosion, these authors postulated that calcite would be removed from the exposed rocks and should no longer be a major contributor to the dissolved load.

Cation exchange in soils is a rapid process compared to chemical weathering that may also result in an increase of the $\mathrm{Na}^{+} / \mathrm{Ca}^{2+}$ ratio (Drever, 1988; Stumm and Morgan, 1996). Williams et al. (1993) observed that the molar ratio of $\mathrm{Na}^{+} / \mathrm{Ca}^{2+}$ increased $230 \%$ during the period of snowpack runoff in extremely dilute stream water. This increase was attributed to soil exchangers replacing the $\mathrm{H}^{+}$in infiltrating snow-melt water with $\mathrm{Na}^{+}$. Many studies have also shown that water of low ionic strength may rapidly acquire substantial amounts of silica from soil (Kennedy, 1971; Zeman and Slaymaker, 1975; Brown and Lund, 1991). In the Val Roseg floodplain, all the channels located on the floodplain margins, including those with low specific conductance, had a high $\mathrm{Na}^{+} / \mathrm{Ca}^{2+}$ ratio and a low $\mathrm{HCO}_{3}{ }^{-} /$ $\mathrm{H}_{4} \mathrm{SiO}_{4}$ ratio. This suggests that during spring and summer, soil contact may be a more important factor than the residence time of the water in the subsurface reservoirs of the catchment slopes.
The $\mathrm{SO}_{4}{ }^{2-} / \mathrm{HCO}_{3}^{-}$Ratio

Another striking characteristic of water in the Val Roseg floodplain is its high average concentration of $\mathrm{SO}_{4}{ }^{2-}$ (average $=$ $147 \mu \mathrm{eq} \mathrm{L}{ }^{-1} ; \mathrm{SD}=94 ; n=247$ ). Atmospheric deposition alone cannot account for the $\mathrm{SO}_{4}{ }^{2-}$ content of surface water. Nickus et al. (1997) showed that the weighted mean concentration of $\mathrm{SO}_{4}{ }^{2-}$ in high alpine snow packs (3000 to $4000 \mathrm{~m}$ a.s.1.) of the European Alps was usually below $15 \mu \mathrm{eq} \mathrm{L}^{-1}$. Snow samples collected in the Val Roseg floodplain as well as ice and supraglacial water samples collected on the Tschierva glacier had $\mathrm{SO}_{4}{ }^{2-}$ concentrations ranging from nondetectable levels to $83 \mu \mathrm{eq} \mathrm{L}^{-1}$ (average $=24 \mu \mathrm{eq} \mathrm{L}{ }^{-1} ; \mathrm{SD}=18 ; n=37$ ). Increasing $\mathrm{SO}_{4}{ }^{2-}$ concentrations during the winter strongly suggest that $\mathrm{SO}_{4}{ }^{2-}$ is in fact generated by weathering processes. There are two possible scenarios; either simple dissolution of evaporitic minerals such as gypsum (equation 4) or anhydrite, or oxidation of pyrite (equation 5) which can then act as a source of protons for weathering other minerals such as calcite.

$$
\mathrm{CaSO}_{4} \cdot 2 \mathrm{H}_{2} \mathrm{O} \rightarrow \mathrm{Ca}^{2+} \mathrm{SO}_{4}{ }^{2-}+2 \mathrm{H}_{2} \mathrm{O}
$$

$\mathrm{FeS}_{2}+15 / 4 \mathrm{O}_{2}+7 / 2 \mathrm{H}_{2} \mathrm{O} \rightarrow \mathrm{Fe}(\mathrm{OH})_{3}+2 \mathrm{SO}_{4}{ }^{2-}+4 \mathrm{H}^{+}$.

Although it is not possible to distinguish between these two alternatives, pyrite oxidation is considered as the most plausible 


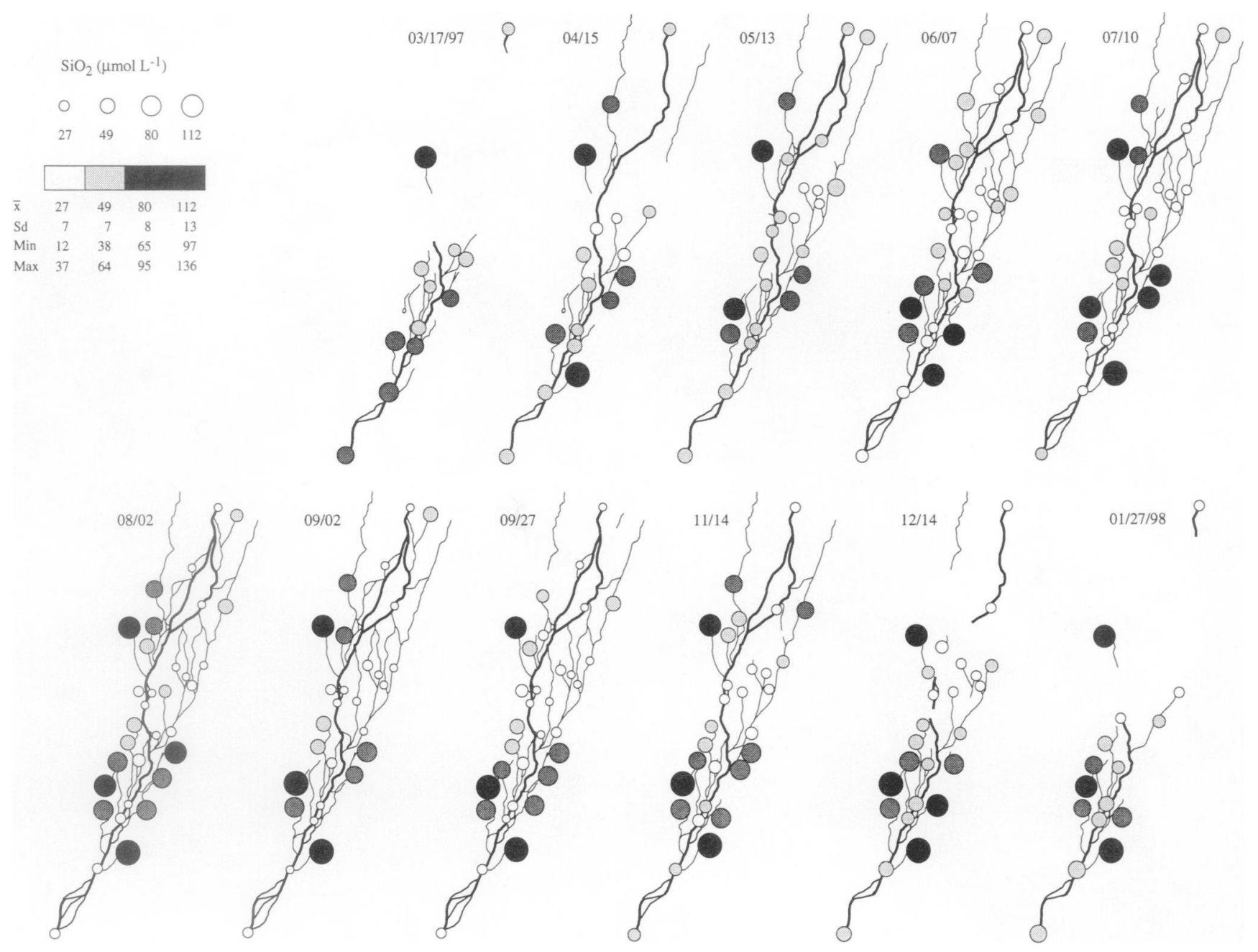

FIGURE 6. Same as in Figure 5 but for $\mathrm{SiO}_{2}$.

source of $\mathrm{SO}_{4}{ }^{2-}$ in the Val Roseg catchment. Since simple dissolution of gypsum or anhydrite occurs at a faster rate than the acid hydrolysis of nonevaporitic minerals, sources of evaporites, if present in a glaciated catchment, should have a marked impact on the composition of glacial water (Tranter et al., 1993). During the ablation period, the bulk meltwater from the Tschierva and Roseg glaciers had comparatively low $\mathrm{SO}_{4}{ }^{2-}$ concentrations and high $\mathrm{Ca}^{2+}$ and $\mathrm{HCO}_{3}{ }^{-}$concentrations due to weathering of carbonate minerals (Table 1). Pyrite oxidation rather than gypsum dissolution has already been reported as the most plausible source of $\mathrm{SO}_{4}{ }^{2-}$ in many catchments composed of igneous and metamorphic rocks (Raiswell and Thomas, 1984; Drever and Hurcomb, 1986; Chillrud et al., 1994; Wögrath and Psenner, 1995). Tranter and Raiswell (1991) and Tranter et al. (1993, 1996) showed that the mass fraction of $\mathrm{SO}_{4}{ }^{2-}\left[\mathrm{SO}_{4}{ }^{2-} /\right.$ $\left.\left(\mathrm{SO}_{4}{ }^{2-}+\mathrm{HCO}_{3}^{-}\right)\right]$in bulk meltwater from three different glaciers increased during the receding limb of the hydrograph. They concluded that pyrite oxidation was promoted by the slow transit of water in the distributed drainage system beneath the glacier, while solutes were acquired mainly by carbonation reactions during the rapid flow of water in the channelized system of the glacier. We also believe that the progressive increase in the $\mathrm{SO}_{4}{ }^{2-}$ concentration and molar ratio of $\mathrm{SO}_{4}{ }^{2-} / \mathrm{HCO}_{3}{ }^{-}$observed in the Val Roseg floodplain during autumn and winter result from longer contact time of subglacial and subsurface water with rock materials (Figs. 4, 8).

\section{$\mathrm{NO}_{3}$ - Concentration}

As in many other mountain areas (Charles, 1991), the seasonal patterns of $\mathrm{NO}_{3}{ }^{-}$concentrations in surface water strongly suggests that the snow is the main source of nitrogen in the Val Roseg catchment. In spring (4 Apr.-7 Jun.), many channels had $\mathrm{NO}_{3}{ }^{-}$concentrations (up to $45 \mu \mathrm{eq} \mathrm{L} \mathrm{L}^{-1} \mathrm{NO}$ ) higher than the total nitrogen concentration measured in the snowpack samples (i.e. $27 \mu$ eq $\mathrm{L}^{-1} \mathrm{~N}$ ). Although the source of the elevated $\mathrm{NO}_{3}{ }^{-}$concentrations in surface water is not yet clear it may be from (1) concentrations by evaporation and flushing of the ionic pulse in snowpack meltwater (Fountain, 1996; Kuhn and Nickus, 1997); (2) leaching of $\mathrm{NO}_{3}{ }^{-}$that accumulates by mineralization and nitrification in the unfrozen soils over winter (Munson and Gherini, 1991; Peters et al., 1998); or (3) additional mineralization and nitrification of organic nitrogen in soils during the spring season.

Although DON represented a high proportion of TDN (i.e. $48 \%$ ) in the snowpack, $\mathrm{NO}_{3}{ }^{-}$was the dominant form (i.e. $87 \%$ ) of nitrogen in surface water. This suggests that DON released from the snowpack is effectively mineralized during the transit of snow-melt water to the floodplain channel network. High concentrations of DON in snowpack are believed to arise from the accumulation of particulates as indicated by the high content of particulate organic carbon ( $\mathrm{POC}=0.9 \mathrm{mg} \mathrm{L}^{-1}$; Tockner, unpublished data) and $\mathrm{Ca}^{2+}$ concentrations $\left(80 \mu \mathrm{eq} \mathrm{L}^{-1}\right)$ in snow sam- 


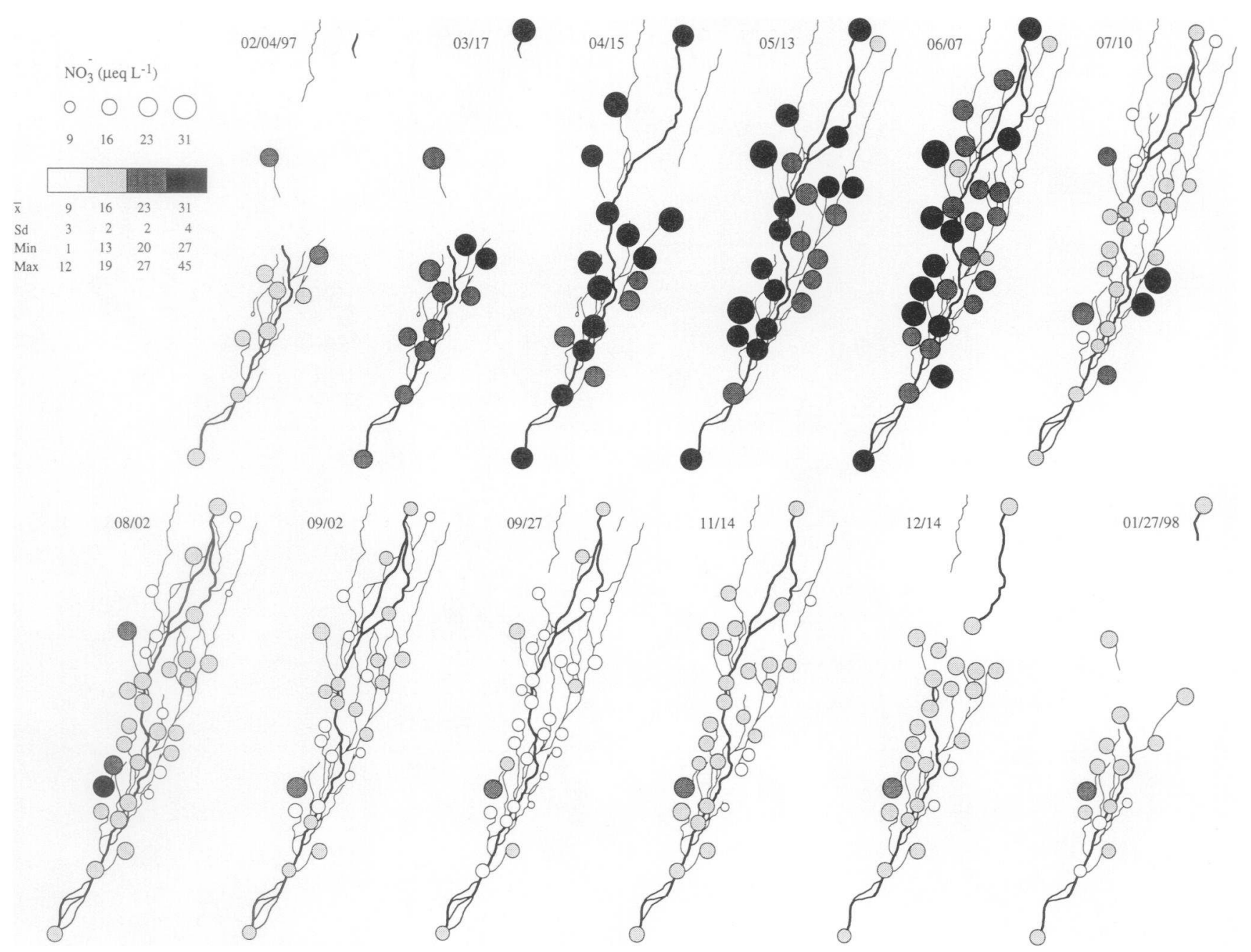

FIGURE 7. Same as in Figure 5 but for $\mathrm{NO}_{3}{ }^{-}$concentrations.

ples collected in March and April. Several investigations have already shown particulates transported by wind to be an important factor for both the base cations and DON content of snowpack (Timperley et al., 1985; Williams and Melack, 1991; Nickus et al., 1997).

\section{A CONCEPTUAL MODEL FOR DESCRIBING SEASONAL SHIFT IN WATER SOURCES AND FLOW PATHS}

Seasonal changes in sources and flow paths of water in the Val Roseg floodplain may be portrayed as follows. Spring (April-June) is a period of increasing discharge and expansion of the channel network (Fig. 9A). The persistence of high $\mathrm{NO}_{3}{ }^{-}$ concentrations, despite a major increase in the discharge, show that the snowmelt is the main source of water to the floodplain. In April and May the high specific conductance and concentrations of base cations in almost every channel of the floodplain indicate that there is little overland flow on the catchment slopes (Figs. 4, 5), which is attributed to the presence of thick morainic and fluvioglacial deposits in the Val Roseg catchment. High $\mathrm{NO}_{3}{ }^{-}$concentrations in early June indicate that melting of the snow is still the main source of water but the distributional pattern of base cations and $\mathrm{SiO}_{2}$ show that there is a change in the hydrologic routing of snow-melt water (Figs 5,7 ). In contrast to the homogeneous spatial pattern observed in April and May, base cations concentrations in June were lower in the main channel and channels having an upstream surface connection with the main channel. Because melting of the snow pack occurs on the glaciers in June, snow-melt water has shorter contact time with rock materials and enters the floodplain via surface flow paths (sites M-1, T3, or T4 in Fig. 1B).

Summer (July-mid-September) corresponds to a phase of high and relatively constant discharge that results in a maximum expansion of the channel network (Fig. 9B). The Roseg and Tschierva glaciers are the main source of water, the bulk of which enters the floodplain via surface flow paths at site M-1. The beginning of the ice ablation period, as glacier ice is exposed by snowline recession, is characterized by the strong decline of $\mathrm{NO}_{3}{ }^{-}$concentrations of surface water in July and a further decrease in specific conductance, $\mathrm{Ca}^{2+}$ and $\mathrm{HCO}_{3}{ }^{-}$. At the Haut Glacier d'Arolla (Switzerland), $\mathrm{NO}_{3}{ }^{-}$and base cation concentrations were also higher in subglacial water fed by snowmelt than in englacial water fed by icemelt (Richards et al., 1996; Tranter et al., 1997). The hydrological connectivity within the floodplain is maximum at this time either due to surface connections between channels or rapid lateral and longitudinal downwelling and upwelling of surface water (e.g. sites Q4, G3, G9, G4 in Fig. 5). Thus, surface flow paths and short subsurface flow paths are dominant, as indicated by the low $\mathrm{SO}_{4}{ }^{2-} / \mathrm{HCO}_{3}{ }^{-}$ measured in most floodplain channels (Fig. 8C). The chemical signature of hillslope aquifers (i.e. higher silica and sodium concentrations and higher $\mathrm{Na}^{+} / \mathrm{Ca}^{2+}$ ratio) is restricted to water bodies located on the margin of the floodplain. Water flow from the 

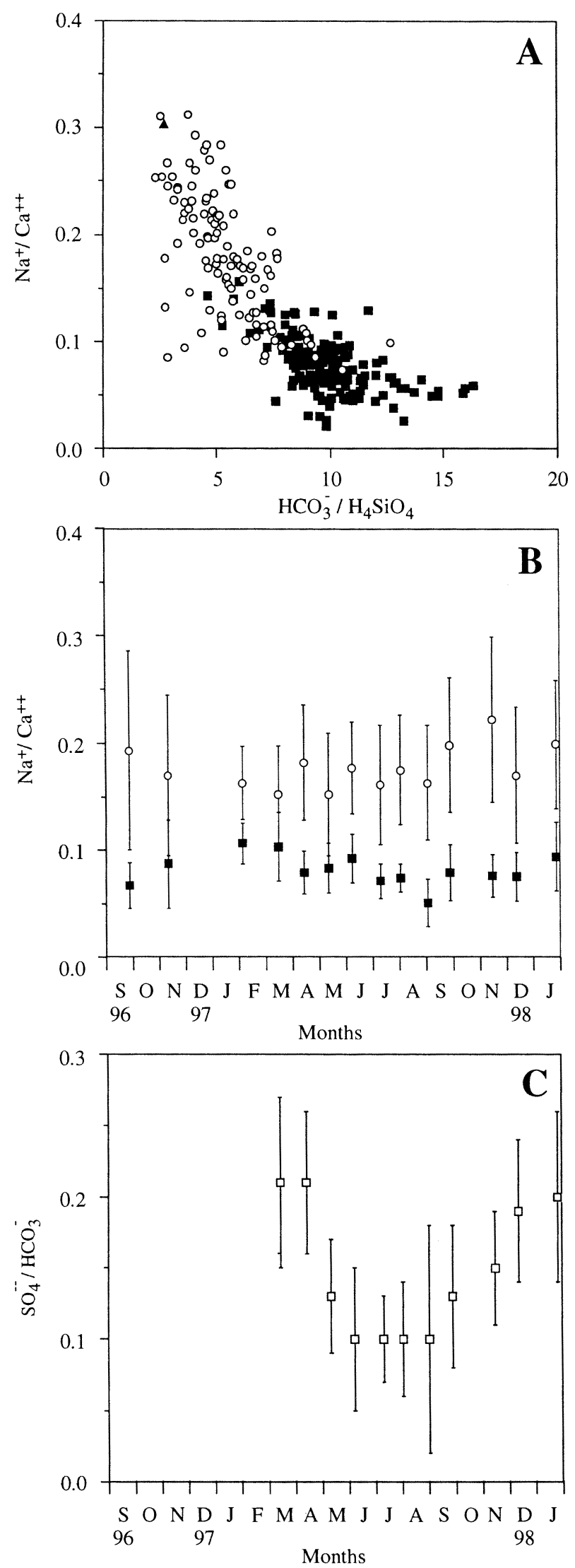

^ Deep alluvial ground water (site GWH)

- Sites located at the margin of the floodplain (G1, G3, G5, G8, G9, Q15, Q4, Q5, T1, T2, T3, T4, T5, X5)

- Sites located within the floodplain (G2, G4, G6, I1, I2. I3, I6, M-1, M5, M10, M12, M15, M20, S1, S2, S3, X1, X2, X3)

․ All sites main channel into the floodplain sediments probably restricts the drainage of hillslope groundwater which upwells on the floodplain terraces and generates extensive marshy areas. Diversion of hillslope groundwater during periods of high water table was reported also by Burt and Haycock (1996) in a floodplain of the Cotswold Hills, England.

Autumn (mid-September-December) is a period of decreasing discharge and contraction of the channel network (Fig. 9C). Despite a two-fold decrease in discharge in September (from 6 to $3 \mathrm{~m}^{3} \mathrm{~s}^{-1}$ ) and a $22 \%$ reduction in the length of the upper channel network (from 14.1 to $11 \mathrm{~km}$ ), specific conductance did not increase, indicating that the contribution of englacial water to the flow had not changed. Major changes in water chemistry and channel length occurred in November and December as discharge decreased from 3 to $0.5 \mathrm{~m}^{3} \mathrm{~s}^{-1}$. There was a strong contraction of the channel network in the upper floodplain (from 11 to $3.5 \mathrm{~km}$ ) and a marked increase in specific conductance and concentrations of most ions. Differences in the concentrations of $\mathrm{SiO}_{2}$ between channels located in the upper and lower floodplains show that two different sources and pathways of water are operating (Fig. 6). Surface water entering the floodplain at site $\mathrm{M}-1$ is composed mainly of subglacial water characterized by high $\mathrm{SO}_{4}{ }^{2-} / \mathrm{HCO}_{3}{ }^{-}$ratio but low $\mathrm{SiO}_{2}$ concentration and $\mathrm{Na}^{+} /$ $\mathrm{Ca}^{2+}$ ratio. Seepage of main channel water is the primary water source of the channel network in the upper floodplain (Fig. 9C). In contrast, surface flow in the lower floodplain is also sustained by upwelling of deep alluvial and hillslope groundwaters, as indicating by the higher $\mathrm{SiO}_{2}$ concentration and $\mathrm{Na}^{+} / \mathrm{Ca}^{2+}$ ratio of surface water.

Winter (January-March) corresponds to a phase of constant and low discharge that results in a maximum contraction of the channel network (Fig. 9D). Because surface water entering the floodplain at site M-1 disappears into the sediment, groundwater is the only water source of the channel network in the lower floodplain. During winter, a decrease in groundwater storage and the resulting decline in the water table induces a further reduction of the channel network. The high specific conductance, $\mathrm{SiO}_{2}$ concentrations and $\mathrm{Na}^{+} / \mathrm{Ca}^{2+}$ ratio measured in almost every channel of the floodplain suggest an increasing contribution of groundwater from deep alluvial and hillslope aquifers. Subsurface flow paths in these aquifers may be relatively long as indicated by the recent results of ${ }^{3} \mathrm{H}$ groundwater dating (Beyerle, U., unpublished data). Groundwaters collected with an inertial pump in February 1998 at sites GW5 (hillslope aquifer) and GWH (deep alluvial aquifer) were 2 and $20 \mathrm{yr}$ old, respectively. However, groundwater at site GW2 (shallow alluvial groundwater) was less than $80 \mathrm{~d}$ old (detection limit of ${ }^{3} \mathrm{H}$ dating) and its chemical composition was similar to that of site M-1. Thus, although seepage of surface water from the main channel is not the main source of water to the floodplain, it still contributes to the flow of water in channels located in the upper floodplain.

$\leftarrow$

FIGURE 8. A. Molar ratio of $\mathrm{Na}^{+}$to $\mathrm{Ca}^{2+}$ plotted versus molar ratio of $\mathrm{HCO}_{3}$ to $\mathrm{H}_{4} \mathrm{SiO}_{4}$ for surface water samples collected from March 1997 to January 1998. B. Temporal changes in the average molar ratio of $\mathrm{Na}^{+}$to $\mathrm{Ca}^{2+}$ of surface water samples collected on the floodplain margins and within the active floodplain. C. Temporal changes in the average molar ratio of $\mathrm{SO}_{4}{ }^{2-}$ to $\mathrm{HCO}_{3}{ }^{2-}$ of surface water. 

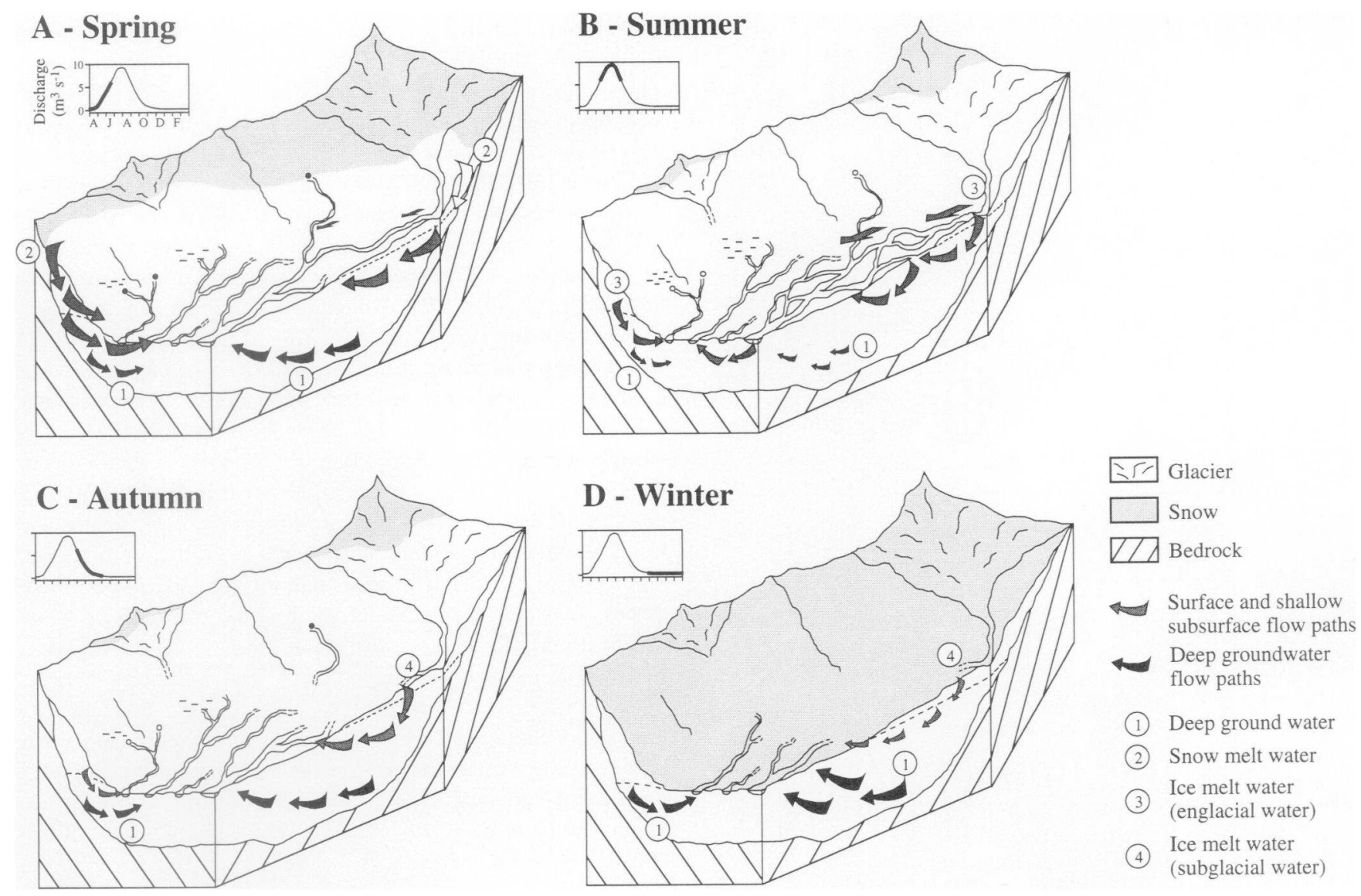

FIGURE 9. Schematic diagram showing the seasonal shift in the sources and flowpaths of water in the Val Roseg floodplain. The river discharge corresponding to each period is indicated in bold. The relative size of the arrows show the relative importance of the different sources and flow paths of water.

\section{Conclusion}

Our investigation highlights the complexity of hydrologic and geochemical processes that govern the solute composition of stream water in a glacial floodplain. Despite this complexity, we were able to develop a qualitative model that relates the seasonal changes in discharge, spatio-temporal patterns of channel length, and water chemistry within the floodplain to the relative importance of different hydrologic reservoirs and flow paths of water operating within the catchment. This conceptual model also accounts for interactions between the floodplain channel network and the alluvial aquifer. In winter, the floodplain channel network may be considered mainly as an alluvial groundwater drainage network but during the other seasons it also exchanges water between different hydrologic reservoirs of the catchment (e.g. from the glaciers to the alluvial aquifer). Current research in the Val Roseg floodplain is determining the influence of seasonal shift in water sources and flow paths on biological attributes of this glacial ecosystem such as the diversity of periphytic, benthic, and hyporheic communities, primary productivity, and the processing of organic matter.

\section{Acknowledgments}

This work was partly funded by the Swiss National Science Foundation (SNF grant 21-49243.96). We thank the numerous individuals who contributed to the success of the field, laboratory, and analytical efforts that culminated in this manuscript, including T. Boesch, P. Burgherr, B. Fassnacht, R. Illi, C. Jolidon, B. Klein, S. Meyns, B. Ribi, C. Robinson, T. Wellnitz, U.
Uehlinger, and R. Zah. We are grateful to Mr. Testa and his crew at the Roseg Hotel for their hospitality and to the communes of Pontresina and Samedan for providing access to the sampling area. Special thanks to E. Hoehn and M. Sturm for stimulating discussions, and especially to W. Stumm, R. Gächter, B. Vaughn, and one anonymous reviewer for their valuable critiques that improved the manuscript.

\section{References Cited}

Allan, J. D. and Johnson, L. B., 1997: Catchment-scale analysis of aquatic ecosystems. Freshwater Biology, 37: 107-111.

APHA, 1989: Standard Methods for the Examination of Water and Wastewater. 17th ed. Washington: American Public Health Association. 1134 pp.

Bencala, K. E., 1993: A perspective on stream-catchment connections. Journal of the North American Benthological Society, 12: 44-47.

Brown, A. D. and Lund, L. J., 1991: Kinetics of weathering in soils from a subalpine watershed. Journal of Soil Science Society of America, 55: 1767-1773.

Brunke, M. and Gonser, T., 1997: The ecological significance of exchange processes between rivers and groundwater. Freshwater Biology, 37: 1-33.

Burt, T. P. and Haycock, N. E., 1996: Linking hillslopes to floodplains. In Anderson, M. G., Des Walling, E., and Bates, P. D. (eds.), Floodplain Processes. Chichester: John Wiley: 461492.

Charles, D. F., 1991: Acidic Deposition and Aquatic Ecosystems. New York: Springer-Verlag. 747 pp.

Chillrud, S. N., Pedrozo, F. L., Temporetti, P. F., Planas, H. F., 
and Froelich, P. N., 1994: Chemical weathering of phosphate and germanium in glacial meltwater streams: effects of subglacial pyrite oxidation. Limnology and Oceanography, 39: 1130-1140.

Christ, P., Günthert, A., and Spicher, A., 1964: Geologische Generalkarte der Schweiz, Blatt 8, Engadin $(1: 200,000)$. Bern, Switzerland: Geographischer Verlag.

Collins, D. N., 1979: Hydrochemistry of meltwaters draining from an alpine glacier. Arctic and Alpine Research, 11: 307324.

de Vries, J. J., 1995: Seasonal expansion and contraction of stream networks in shallow groundwater systems. Journal of Hydrology, 170: 15-26.

Downes, M.T., 1978: An improved hydrazine reduction method for the automated determination of low nitrate levels in freshwater. Water Research, 12: 673-675.

Drever, J. I. and Hurcomb, D. R., 1986: Neutralization of atmospheric acidity by chemical weathering in an alpine drainage basin in the North Cascade Mountains. Geology, 14: 221224.

Drever, J. I., 1988: The Geochemistry of Natural Waters. 2nd ed. Englewood Ciffs. N.J.: Prentice Hall. 437 pp.

Driscoll, C. T., Newton, R. M., Gubala, C. P., Baker, J. P., and Christensen, S. W., 1991: Adirondack Moutains. In Charles, D. F. (ed.), Acidic Deposition and Aquatic Ecosystems. New York: Springer-Verlag, 133-202.

Ebina, L., Tsutsui, T., and Shirai, T., 1983: Simultaneous determination of total nitrogen and total phosphorus in water using peroxodisulfate oxidation. Water Research, 17: 1721-1726.

Forsberg, B. R., Devol, A. H., Richey, J. E., Martinelli, L. A., and dos Santos, H., 1988: Factors controlling nutrient concentrations in Amazon floodplain lakes. Limnology and Oceanography, 33: 41-56.

Fountain, A. G., 1996: Effect of snow and firm hydrology on the physical and chemical characteristics of glacial runoff. $\mathrm{Hy}$ drological Processes, 10: 509-521.

Garrels, R. M., 1967: Genesis of some ground waters from igneous rocks. In Abelson, P. H. (ed.), Researches in Geochemistry. Vol. 2. New York: John Wiley, 405-420.

Heiler, H., Hein, T., Schiemer, F., and Bornette, G., 1995: Hydrological connectivity and flood pulses as the central aspects for the integrity of a river-floodplain system. Regulated Rivers, 11: 351-361.

Hynes, H. B. N., 1975: The stream and its valley. Verhandlungen der Internationalen Vereinigung für Theoretische und Angewandte Limnologie, 19: 1-15.

Jolly, I. D., 1996: The effects of river management on the hydrology and hydroecology of arid and semi-arid floodplains. In Anderson, M. G., Des Walling, E., and Bates, P. D. (eds.), Floodplain Processes. Chichester: John Wiley, 577-609.

Kennedy, V. C., 1971: Silica variation in stream water with time and discharge. In Hem, J. D. (ed.), Nonequilibrium Systems in Natural Water Chemistry. Advances in Chemistry Series, 106. Washington, D.C.: American Chemical Society, 94-130.

Kuhn, M. and Nickus, U., 1997: High alpine snow pack chemistry. In Fuzzi, S. and Wagenbach, D. (eds.), Cloud Multiphase Processes and High Alpine Air and Snow Chemistry. Berlin: Springer, 203-209.

Maisch, M., 1988: Die Veränderungen der Gletscherflächen und Schneegrenzen seit dem Hochstand von 1850 im Kanton Graubünden (Schweiz). Zeitschrift für Geomorphologie Neue Folge Supplementband, 70: 113-130.

Malard, F., Ward, J. V., and Robinson, C. T., (in press): An expanded perspective of the hyporheic zone. Verhandlungen der Internationalen Vereinigung für Theoretische und Angewandte Limnologie, 27.

Mast, M. A., Drever, J. I., and Baron, J., 1990: Chemical weathering in the Loch Vale watershed, Rocky Mountain National Park, Colorado. Water Resources Research, 26: 2971-2978.
Milner, A. M. and Petts, G. E., 1994: Glacial rivers: physical habitat and ecology. Freshwater Biology, 32: 295-307.

Munson, R. K. and Gherini, S. A., 1991: Processes influencing the acid-base chemistry of surface waters. In Charles, D. F. (ed.), Acidic Deposition and Aquatic Ecosystems. New York: Springer-Verlag, 9-34.

Nickus, U., Kuhn, M., Baltensperger, U., Delmas, R., Gäggeler, H., Kasper, A., Kromp-Kolb, H., Maupetit, F, Novo, A., Pichlmayer, F., Seibert, P., Staudinger, M., Trockner, V., Wagenbach, D., and Winiwarter, W., 1997: SNOSP: ion deposition and concentration in high alpine snow packs. Tellus, 49B: 5671 .

Parch, K., Jenik, J., and Large, A. R. G., 1996: Floodplain Ecology and Management, the Luznice River in the Trebon Biosphere Reserve, Central Europe. Amsterdam: SPB Academic Publishing. $285 \mathrm{pp}$.

Peters, N. E., Cerny, J., and Havel, M., 1998: Factors controlling streamwater nitrate concentrations in a forested headwater catchment, Krusne Hory Mountains, Czech Republic. In Haigh, M. J., Krecek, J., Rajwar, G. S., and Kilmartin, M. P. (eds.), Headwaters: Water Resources and Soil Conservation. Rotterdam: A.A. Balkema, 147-157.

Petts, G. E. and Amoros, C., 1996: Fluvial Hydrosystems. London: Chapman and Hall. 322 pp.

Raiswell, R. and Thomas, A. G., 1984: Solute acquisition in glacial melt waters. I. Fjallsjökull (South-east Iceland): bulk melt waters with closed-system characteristics. Journal of Glaciology, 30(104): 35-43.

Richards, K., Sharp, M., Arnold, N., Gurnell, A., Clark, M., Tranter, M., Nienow, P., Brown, G., Willis, I., and Lawson, W., 1996: An integrated approach to modelling hydrology and water quality in glacierized catchments. Hydrological Processes, 10: 479-508.

Rodier, D., 1996: L'analyse de l'Eau. 8th ed. Paris: Dunod. 1136 pp.

Roux, A. L., 1982: Cartographie polythématique appliquée à la gestion écologique des eaux. Etude d'un hydrosystème fluvial: le Haut-Rhône français. Paris: Centre National de la Recherche Scientifique. 133 pp.

Spreafico, M., Leibundgut, C., and Weingartner, R., 1992: Hydrological Atlas of Switzerland. Bern, Switzerland: Hydrological and Geological Swiss Survey.

Stallard, R. F. and Edmond, J. M., 1983: Geochemistry of the Amazon. 2. The influence of geology and weathering environment on the dissolved load. Journal of Geophysical Research, 88(C14): 9671-9688.

Stanford, J. A., and Ward, J. V., 1993: An ecosystem perspective of alluvial rivers: connectivity and the hyporheic corridor. Journal of the North Benthological Society, 12: 48-60.

Stanley, E. H., Fisher, S. G., and Grimm, N. B., 1997: Ecosystem expansion and contraction in streams. BioScience, 47: 427435.

Staub, R., 1946: Geologische Karte der Bernina-Gruppe (1: 50,000). Bern, Switzerland: Geographischer Verlag.

Stauffer, R. E., 1990: Granite weathering and the sensitivity of alpine lakes to acid deposition. Limnology and Oceanography, 35: 1112-1134.

Stumm, W. and Morgan, J. J., 1996: Aquatic Chemistry. 3rd ed. New York: Wiley Interscience. 1022 pp.

Thioulouse, J., 1989: Statistical analysis and graphical display of multivariate data on the Macintosh. Computer Applications in the Biosciences, 5: 287-292.

Timperley, M. H., Vigor-Brown, R. J., Kawashima, M., and Ishigami, M., 1985: Organic nitrogen compounds in atmospheric precipitation: their chemistry and availability to phytoplankton. Canadian Journal of Fisheries and Aquatic Sciences, 42: 1171-1177.

Tockner, K., Malard, F., Burgherr, P., Robinson, C. T., Uehlinger U., Zah, R., and Ward, J.V., 1997: Physico-chemical characterization of channel types in a glacial floodplain ecosystem 
(Val Roseg, Switzerland). Archiv für Hydrobiologie, 140: 433463.

Townsend, C. R., 1996: Concepts in river ecology: pattern and process in the catchment hierarchy. Archiv für Hydrobiologie Supplement, 113: 3-21.

Tranter, M. and Raiswell, R., 1991: The composition of the englacial and subglacial component in bulk meltwaters draining the Gornergletscher, Switzerland. Journal of Glaciology, 37(125): 59-66.

Tranter, M., Brown, G. H., Hodson, A. J., and Gurnell, A. M., 1996: Hydrochemistry as an indicator of subglacial drainage system structure: a comparison of alpine and sub-polar environments. Hydrological Processes, 10: 541-556.

Tranter, M., Brown, G., Raiswell, R., Sharp, M., and Gurnell, A., 1993: A conceptual model of solute acquisition by Alpine glacial meltwaters. Journal of Glaciology, 39(133): 573-581.

Tranter, M., Sharp, M. J., Brown, G. H., Willis, I. C., Hubbard, B. P., Nielsen, M. K., Smart, C. C., Gordon, S., Tulley, M., and Lamb, H. R., 1997: Variability in the chemical composition of in situ subglacial meltwaters. Hydrological Processes, 11: 59-77.

Valett, H. M., Morrice, J. A., and Dahm, C. N., 1996: Parent lithology, surface-groundwater exchange, and nitrate retention in headwater streams. Limnology and Oceanography, 41: 333345.
Ward J. V., Malard, F, Tockner, K., and Uehlinger, U., 1999a: Influence of ground water on surface water conditions in a glacial flood plain of the Swiss Alps. Hydrological Processes (in press).

Ward, J. V., Tockner, K., Edwards, P. J., Kollmann, J., Bretschko, G., Gurnell, A. M., Petts, G. E., and Rossaro, B., 1999b: A reference river system for the Alps: the Fiume Tagliamento. Regulated Rivers (in press).

Williams, M. W. and Melack, J. M., 1991: Solute chemistry of snowmelt and runoff in an alpine basin, Sierra Nevada. Water Resources Research, 27: 1575-1588.

Williams, M. W., Brown, A. D., and Melack, J. M., 1993: Geochemical and hydrologic controls on the composition of surface water in a high-elevation basin, Sierra Nevada, California. Limnology and Oceanography, 38: 775-797.

Wögrath, S. and Psenner, R., 1995: Seasonal, annual and longterm variability in the water chemistry of a remote high moutain lake: acid rain versus natural changes. Water, Air and Soil Pollution, 85: 359-364.

Zeman, L. J. and Slaymaker, H. O., 1975: Hydrochemical analysis to discriminate variable runoff source areas in an alpine basin. Arctic and Alpine Research, 7: 341-351.

Ms submitted July 1998 